\title{
Evaluation of skin sensitivity in dogs bearing allergic dermatitis to standardized allergenic extract of house dust and storage mites ${ }^{1}$
}

\author{
Victor E.S. Cunha ${ }^{2 *}$, Ruppert L. Hahnstadt ${ }^{3}$, Ana Maria B. Soares ${ }^{4}$ and \\ João Luiz H. Faccini ${ }^{2 * * *}$
}

\begin{abstract}
Cunha V.E. S., Hahnstadt R.L., Soares A.M.B. \& Faccini J.L.H. 2007. Evaluation of skin sensitivity in dogs bearing allergic dermatitis to standardized allergenic extracts of house dust mites. Pesquisa Veterinária Brasileira 27(8):341-344. Curso de Pós-Graduação em Ciência Veterinária, Universidade Federal Rural do Rio de Janeiro, Seropédica, RJ 23890-000, Brazil E-mail: mvvictor@ufrrj.br

The objective of the study was to evaluate whether allergenic extracts of five house dust and storage mite species standardized for humans might be used for the diagnosis of canine atopic dermatitis (CAD). Extracts of Dermatophagoides pteronyssinus (Pyroglyphidae), D. farinae (Pyroglyphidae), Blomia tropicalis (Glycyphagidae), Lepidoglyphus destructor (Glycyphagidae) and Tyrophagus putrescentiae (Acaridae) were evaluated by intradermal testing in 20 healthy dogs (control) and 25 dogs with allergic dermatitis. A significant difference in the response was observed between the two groups $(\mathrm{p}<0.05)$. Only one dog $(5 \%)$ in the control group reacted to the intradermal test, whereas $14 \operatorname{dogs}(56 \%)$ in the allergic group were positive for at least one extract (odds ratio $=24.2$ ). Most of the positive reactions observed in the allergic group occurred against the extracts of T. putrescentiae or $L$. destructor, each inducing reactions in 10 dogs $(40 \%)$. D. farinae, D. pteronyssinus e B. tropicalis extracts induced reactions in $7(28 \%), 3$ $(12 \%)$ and $3(12 \%)$ dogs, respectively. The allergenic extracts standardized for humans evaluated in the present study may be used as a tool to complement the diagnosis of the disease, as well as to select potential allergen candidates for allergen-specific immunotherapy.
\end{abstract}

INDEX TERMS: Dust mites, allergy, canine atopic dermatitis, intradermal test.

RESUMO.- [Avaliação da sensibilidade de cães com dermatite alérgica a extratos padronizados de ácaros da poeira domiciliar.] $O$ presente trabalho teve como objetivo avaliar se extratos alergênicos de cinco espécies de ácaros da poeira domiciliar e produtos armazenados, padronizados para humanos, podem ser utilizados no diagnóstico da dermatite atópica canina. Extratos de Dermatophagoides pteronyssinus (Pyroglyphidae), D. farinae (Pyroglyphidae), Blomia tropicalis

\footnotetext{
${ }^{1}$ Received on July 10, 2007.

Accepted for publication on August 15, 2007.

${ }^{2}$ Curso de Pós-Graduação em Ciência Veterinária (CPGCV), Universidade Federal Rural do Rio de Janeiro (UFRRJ), Seropédica, RJ 23890-000, Brazil. * Corresponding author: mvvictor@ufrrj.br; *** Fellow of CNPq.

${ }^{3}$ FDA-Allergenic Ltda, Rua da Abolição 413, Abolição, Rio de Janeiro, RJ 20755-170, Brazil.

${ }^{4}$ Departamento de Clínica de Pequenos Animais, Faculdade de Veterinária, Universidade Federal Fluminense (UFF), Rua Vital Brasil Filho 64, Santa Rosa, Niterói, RJ 24230-340, Brazil.
}

(Glycyphagidae), Lepidoglyphus destructor (Glycyphagidae) e Tyrophagus putrescentiae (Acaridae) foram avaliados através de testes intradérmicos em 45 cães, dos quais 20 normais e 25 com dermatite alérgica. Uma diferença significativa foi observada no padrão de respostas obtidas dos dois grupos $(\mathrm{p}<0.05)$. Apenas um animal (5\%) do grupo controle reagiu ao teste cutâneo, enquanto que no grupo dos alérgicos 14 cães (56\%) apresentaram pelo menos uma reação positiva (odds ratio $=24.2$ ). As maiores frequiências de reações positivas observadas no grupo dos alérgicos foram aos extratos de T. putrescentiae ou L. destructor, cada um induzindo reações em 10(40\%) cães. Os extratos de D. farinae, D. pteronyssinus e B. tropicalis foram responsáveis por reações positivas em $7(28 \%), 3(12 \%)$ e $3(12 \%)$ cães, respectivamente. Os extratos padronizados para humanos avaliados no presente estudo podem ser utilizados como complemento no diagnóstico da doença, assim como na seleção de alérgenos para a imunoterapia alérgeno-específica. 
TERMOS DE INDEXAÇÃO: Ácaros, poeira domiciliar, alergia, dermatite atópica canina, teste intradérmico.

\section{INTRODUCTION}

Canine atopic dermatitis (CAD) is a genetically predisposed inflammatory and pruritic allergic skin disease most commonly associated with IgE antibodies in response to environmental allergens (Olivry et al. 2001). Numerous allergens have been suggested to be involved in the pathogenesis of CAD, including house dust and storage mite antigens. House dust and storage mites are considered to be the main cause of atopic diseases in dogs and humans (Swinnen \& Vroom 2004), and may affect between $30 \%$ and $100 \%$ of dogs with CAD (Randall et al. 2003). Brazil is a tropical country where the relative humidity and annual average temperature are around $70 \%$ and $27^{\circ} \mathrm{C}$, respectively. These conditions are highly suitable for the growth of house dust mites and the most commonly genera found in Brazil belong to the families Pyroglyphidae, Glycyphagidae, Cheyletidae, and Acaridae (Binotti et al. 2001).

The diagnosis of CAD is based on history and clinical presentation and is further supported by positive reactions to specific allergens determined by intradermal skin test (IDST), enzyme-linked immunosorbent assay (ELISA) and radioallergosorbant tests (RAST) (Scott et al. 2000). The primary goal of these procedures is allergen-specific immunotherapy and adequate management of sensitive dogs (Swinnen \& Vroom 2004).

IDST is thought to be the most specific of the three tests (Scott et al. 2000). However, most allergenic extracts used in veterinary medicine have not been adequately quantified, with the amount of allergens being measured either as protein nitrogen unit (PNU) or weigh/volume ratio (w/v). As a consequence, the bioactivity of an extract may vary from 10 to 1,000 times among extracts with the same concentration (Reedy et al. 1997). Moreover, allergenic extracts are complex mixtures of antigenic components and total protein content is not necessarily related to allergenic content (Carreira 1992). Therefore, false-positive and false-negative reactions may occur when the bioactivity of the extract is very high or very low, respectively. To ensure reproducible results in the diagnosis and therapy of allergic diseases, standardization of allergenic extracts is essential (Dreborg 1993, AAAAI 1997).

The objective of the present study was to evaluate whether allergenic extracts of house dust and storage mites standardized for humans might be used as a complementary tool in the diagnosis of CAD associated with these groups of mites.

\section{MATERIALS AND METHODS}

\section{Animals}

The present study was carried out according to the ethical principles established by the Brazilian College of Animal Experimentation (COBEA). In the first phase of the study, 20 healthy dogs (control group) of various breeds, ranging in age from 10 months to 11 years (mean age of 4.8 years), were tested in order to determine whether the selected extracts were able to provoke false-positive reactions. These dogs had no history or symptoms of any type of allergic dermatitis or any other dermatologic symptom, and were not receiving any kind of treatment.

A second group included 25 dogs (allergic group) of various breeds, ranging in age from 12 months to 11 years old (mean age of 4.4 years), with a clinical diagnosis of atopic dermatitis according to the criteria proposed by Willemse (1986) and Prélaud et al. (1998). Dogs from this group were examined clinically and tested at private clinics in the city of Rio de Janeiro.

The following procedures were used to exclude etiologies of pruritic dermatoses other than allergic ones. For flea dermatitis, animals with fleas, flea feces or dermatitis/alopecia in the dorsolumbar region detected during clinical examination or with a recent history of flea infestation ( 3 months) were excluded. For the exclusion of scabies, otoacariasis or demodicosis, microscopical examination of skin scrapings and/or acaricide screening (two subcutaneous applications of $0.3 \mathrm{mg} / \mathrm{kg}$ ivermectin at an interval of 14 days) were carried out. Since following a strict diet might be very difficult or impossible for some owners (Scott et al.2000), the possibility of adverse food reactions in dogs of the allergic group could not be excluded. Finally, for secondary infections caused by bacteria or Malassezia sp. diagnosed during clinical examination or by laboratory tests, the dogs received specific systemic treatment (oral cephalexin, $22-30 \mathrm{mg} / \mathrm{kg}$, twice daily or oral ketoconazole $10 \mathrm{mg} / \mathrm{kg}$, once per day, respectively), combined with a twice weekly application of a $2-4 \%$ chlorhexidine or $2.5-3.5 \%$ benzoyl peroxide shampoo for 3 weeks, before inclusion in the study. Only animals that were still pruritic and had lesions compatible with atopic dermatitis after resolution of infections were chosen.

\section{Intradermal testing}

IDST was performed according to standard methods (Reedy et al. 1997, Scott et al. 2000, Zur et al. 2002). The allergenic extracts of the five house dust and storage mite species tested and the control solutions were supplied by FDA-Allergenic Ltda. (Rio de Janeiro, Brazil), the exclusive representative of ALK-ABELLÓ Antigen Laboratories (Horsholm, Denmark) in Brazil. Standardized allergenic extracts of Dermatophagoides pteronyssinus (Pyroglyphidae), D. farinae (Pyroglyphidae), Blomia tropicalis (Glycyphagidae), Lepidoglyphus destructor (Glycyphagidae) and Tyrophagus putrescentiae (Acaridae) (ALKABELLÓ) were tested. The extracts of $D$. pteronyssinus, $D$. farinae and L. destructor were standardized in biological units (BU) and mass units (UM ${ }^{\circledR}$ ALK-ABELLÓ), whereas the extracts of $B$. tropicalis and $T$. putrescentiae were standardized in BU. Extracts of $D$. pteronyssinus e $D$. farinae contained $0.4 \mu \mathrm{g} / \mathrm{ml}$ of Der $\mathrm{p} 1$ and Der $\mathrm{f} 1$ and $0.2 \mu \mathrm{g} / \mathrm{ml}$ of Der $\mathrm{p} 2$ and Der $\mathrm{f}$, respectively, equivalent to a biological activity of $1 \mathrm{BU} / \mathrm{ml}$. Extracts of $L$. destructor contained $0.3 \mu \mathrm{g} / \mathrm{ml}$ of Lep d 1 , corresponding to $1 \mathrm{BU} / \mathrm{ml}$. Extracts of B. tropicalis and T. putrescentiae presented a biological activity of $1 \mathrm{BU} / \mathrm{ml}$. Saline and $0.01 \%$ histamine were used as negative and positive control, respectively.

The chest of the animals was carefully shaved and injection sites were marked with indelible ink. When necessary, the dogs were sedated with atropine/xylazine hydrochloride or atropine/tiletamine/ zolazepan (Hiller \& DeBoer 2001). A volume of $0.05 \mathrm{ml}$ of either the allergenic extracts or control solutions was injected intradermally using an insulin syringe and a $0.5 \mathrm{~mm}$ sterile needle. Wheal diameters were measured with a caliper $15-20 \mathrm{~min}$ after injection. Skin reactions were evaluated objectively and a positive reaction was defined as a wheal diameter, calculated as the mean of the longest diameter and the diameter perpendicular to it, equal to or greater than the mean of the reaction diameters obtained for the positive and negative controls (Reedy et al. 1997, Scott et al. 2000, Hiller \& DeBoer 2001). 


\section{Statistical analysis}

The chi-squared test $(\mathrm{p}<0.05)$ was used to determine significant differences in the prevalence of positive reactions between groups (Sampaio 2002). Odds ratios were considered to be significant when the 95\% confidence interval did not include one (Pereira 1995). Statistical analysis was performed using the SPSS software, version 13.0.

\section{RESULTS}

Fourteen (56\%) of the 25 dogs bearing allergic dermatitis presented positive reactions. Table 1 displays the distribution of reactions among positive dogs.

Table 1. Dogs in the allergic group showing positive reactions

\begin{tabular}{lc}
\hline \multicolumn{1}{c}{ Mites } & $\begin{array}{c}\text { Positive } \\
\text { dogs }\end{array}$ \\
\hline Tyrophagus putrescentiae & 3 \\
Lepidoglyphus destructor + T. putrescentiae & 3 \\
Dermatophagoides farinae + L. destructor & 2 \\
D. farinae + T. putrescentiae & 1 \\
D. pteronyssinus + L. destructor & 1 \\
D. pteronyssinus + D. farinae + L. destructor & 1 \\
D. pteronyssinus + D. farinae + L. destructor + T. putrescentiae & 2 \\
D. pteronyssinus + D. farinae + L. destructor + T. putrescentiae + Blomia tropicalis & 1
\end{tabular}

Only one (5\%) of the 20 dogs tested in the control group reacted positively to both the Blomia tropicalis and Tyrophagus putrescentiae extracts.

Dogs in the allergic group presented a 24.2 times $(95 \% \mathrm{Cl}$ : 2.79-209.76) higher chance of responding to at least one extract compared to control animals.

\section{DISCUSSION}

The use of allergenic extracts standardized for humans in the diagnosis of CAD has been questioned by some investigators (McCall et al. 2001, Nuttall et al. 2006) and supported by others (Carlotti 2001). The allergenic extracts used in the present study were standardized in $\mathrm{BU}$ or in $\mathrm{BU}$ and $\mathrm{UM}^{\circledR}$. The advantages of using these extracts compared to those whose concentration is reported as PNU or $\mathrm{w} / \mathrm{v}$ is that their biological activity and qualitative composition are well known (Carlotti 2001).

Positive reactions on healthy dogs may occur as a consequence of subclinical hypersensitivity, improper use of allergenic extracts, skin inflammation, or irritation caused by the allergenic extracts due to high concentrations of the allergens or contamination (Hiller \& DeBoer 2001). The extract concentrations used in the present study were not considered to be irritating since the prevalence of positive reactions in healthy dogs was less than $10 \%$ (Reedy et al. 1997). However, since the objective of this study was to evaluate commercially available standardized extracts, it is possible that the concentrations were lower than the ideal concentrations, a fact that may have resulted in false-negative reactions in the allergic group.

The present study showed a significant difference $(\mathrm{p}<0.05)$ in the prevalence of positive reactions to the Tyrophagus putrescentiae extract between the allergic and control groups. Mueller et al. (2005) had not observed significant differences in the number of positive reactions between 21 healthy dogs and 26 dogs bearing atopic dermatitis submitted to IDST with different concentrations of $T$. putrescentiae extracts. These contradictory results might be due to the concentrations of the allergenic extracts used in the study of those authors, which were standardized in $\mathrm{PNU} / \mathrm{ml}$ instead of $\mathrm{BU} / \mathrm{ml}$, thus impairing the comparison of the results between the two studies. Moreover, the extracts used herein were not irritating and were standardized in BU and, therefore, false-positive reactions were more unlikely to occur, in contrast to extracts standardized in PNU or $\mathrm{w} / \mathrm{v}$.

T. putrescentiae is the most common storage mite found in samples of house dust in Brazil (Binotti et al. 2001). Although the presence of this species in the habitat of the allergic dog has not been properly evaluated in Brazil, the results of the present study highlight the importance of including storage mite extracts in the set of allergens used in the city of Rio de Janeiro for the diagnosis of CAD. The use of these extracts in other parts of the world where the presence of this species has already been confirmed should be taken into consideration.

Most studies evaluating the skin sensitivity of dogs have demonstrated a high prevalence of positive reactions to the house dust mites Dermatophagoides pteronyssinus and D. farinae, but not to storage mites. This finding might be due to the lack of inclusion of storage mites extracts in the tests. Moreover, qualitative and quantitative differences in the composition of the house dust mite fauna between different regions of the world cannot be ruled out.

All 14 positive dogs in the allergic group reacted to the Lepidoglyphus destructor and/or T. putrescentiae extracts and 6 (43\%) of them reacted to both mite species. A strong crossreactivity between these storage mites has been reported for humans (Tee 1994) and a similar situation may have influenced the outcome of some of the reactions observed in this study.

The results of the present study suggest that, although being standardized for humans, the allergenic extracts employed here might be useful to identify dogs sensitive to the house dust and storage mite species tested. Actually, extracts standardized for humans in $\mathrm{UM}^{\circledR}$ may not offer any advantage over extracts standardized in BU for the diagnosis of DAC. This is the case of the $D$. pteronyssinus e $D$. farinae extracts since the major allergens for dogs differ from those described for humans (McCall et al. 2001, Nuttall et al. 2006). Nevertheless, minor allergens with high molecular weight present in the $D$. farinae extracts may have been responsible for some of the positive reactions observed in the allergic group. Major allergens for a given species are those responsible for causing positive reactions in more than $50 \%$ of the population allergic to the allergen studied, and minor allergens are those able to induce positive reactions in less than $50 \%$ of the allergic population. Both types of allergens are clinically important. All minor allergens identified throughout the process of standardization of the allergenic extracts, although not quantified in $\mathrm{UM}^{\circledR}$, must also be present in the batches commercially available for clinical use (Carreira 1992). The relevance of $L$. destructor extracts standardized in $\mathrm{UM}^{\circledR}$ for the diagnosis of DAC is still unknown. 
It is possible that some allergens important for dogs have not been identified as major or minor allergens in humans and, therefore, may be absent in the extracts used in this study. In this case, false-negative reactions might have occurred. However, the possible absence of relevant allergens also applies to the extracts standardized in PNU or w/v. Nevertheless, as long as the major allergens for dogs are not known and are not included in constant quantities in the allergenic extracts used for the diagnosis of CAD, the allergenic extracts standardized for humans evaluated in the present study may be used as a tool to complement the diagnosis of the disease, as well as to select potential allergen candidates for allergenspecific immunotherapy.

\section{REFERENCES}

AAAAI 1997. Position Statement: the use of standardized allergen extracts. J. All.. Clin. Immunol. 99(5):583-586.

Binotti R.S., Muniz J.R.O., Paschoal I.A., Prado A.P. \& Oliveira C.H. 2001. House dust mites in Brazil, an annotated bibliography. Mem. Inst. Oswaldo Cruz 96(8):1177-1184.

Carlotti D.N. 2001. Long term management of canine atopic dermatitis. In: Proc. World Small Anim. Vet. Assoc. Congr., Vancouver. Available at: www.vin.com/VINDBPub/SearchPB/Proceedings/PR05000/PR00099.htm. Accessed Mar. 16, 2006.

Carreira J. 1992. Cuantification de Alergenos en Unidades de Masa. Editora Alergia e Inmunología Abelló, Madrid. 75p.

Dreborg S. 1993. Standardization of allergenic preparations by in vitro and in vivo methods. Allergy 48(Suppl.14):63-70.

Hiller A. \& DeBoer D.J. 2001. The ACVD task force on canine atopic dermatitis (XVII): intradermal testing. Vet. Immunol. Immunopathol. 81(3-4):289304.

McCall C., Hunter S., Stedman K., Weber E., Hillier A., Bozic C., Rivoire B. \& Olivry T. 2001. Characterization and cloning of a major high molecular weight house dust mite allergen (Der f 15) for dogs. Vet. Immunol. Immunopathol. 78(3-4):231-247.
Mueller R.S., Fieseler K.V., Rosychuck R.A.W. \& Greenwalt T. 2005. Intradermal testing with the storage mite Tyrophagus putrescentiae in normal dogs and dogs with atopic dermatitis in Colorado. Vet. Dermatol. 16(1):27-31.

Nuttall T.J., Hill P.B., Bensignor E., Willense T. and the Members of the International Task Force on Canine Atopic Dermatitis 2006. House dust and forage mites allergens and their role in human and canine atopic dermatitis. Vet. Dermatol.17(4):223-235.

Olivry T., DeBoer D.J., Griffin C.E., Halliwell R.E.W., Hill P.B., Hillier A., Marsella R. \& Sousa C.A. 2001.The ACVD task force on canine atopic dermatitis: forewords and lexicon. Vet. Immunol. Immunopathol. 81(34):143-146.

Pereira M.G.1995. Epidemiologia: Teoria e prática. Guanabara Koogan, Rio de Janeiro. 596p.

Prélaud P., Guaguère E., Alhaidari Z., Heripret D., Faivre N. \& Gayerie A. 1998. Réévaluation des critères diagnostiques de la dermite atopique. Revue Méd. Vét. 149(11):1057-1064.

Randall A., Hillier A., Cole L.K., Kwochka K.W., Needham G. \& Wassom D.L. 2003. Quantitation of house dust mites and house dust mite allergens in the microenvironment of dogs. Amer. J. Vet. Res. 64(12): 1580-1588.

Reedy L.M., Miller W.H. \& Willense T. 1997. Allergic Skin Disease of Dog and Cat. $2^{\text {nd }}$ ed. W.B. Saunders, Philadelphia. 267p.

Sampaio I.B.M. 2002. Estatística Aplicada à Experimentação Animal. $2^{\text {nd }}$ ed. Fundação de Estudo e Pesquisa em Medicina Veterinária e Zootecnia, Belo Horizonte. 265p.

Scott D.W., Miller H.W. \& Griffin C.E. 2000. Mueller and Kirk's Small Animal Dermatology. $6^{\text {th }}$ ed. W.B. Saunders, Philadelphia. 1528p.

Swinnen C. \& Vroom M. 2004.The clinical effect of environmental control of house dust mites in 60 house dust mite-sensitive dogs. Vet. Dermatol. 15(1):31-36

Tee R.D. 1994. Allergy to storage mites. Clin. Exp. Allergy 24(7):636-640.

Willemse T. 1986. Atopic skin disease: a review and a reconsideration of diagnostic criteria. J. Small Anim. Pract. 27(11):771-778.

Zur G., White S.D., Ihrke P.J., Kass P.H. \& Toebe N. 2002. Canine atopic dermatitis: a retrospective study of 169 cases examined at the University of California, Davis, 1992-1998. Part II. Response to hyposensitization. Vet. Dermatol. 13(2):103-111. 